\title{
COMPARISON OF TWO BENZODIAZEPINES FOR ANAESTHESIA INDUCTION: MIDAZOLAM AND DIAZEPAM*
}

\author{
J.G. Reves, Guenter Corssen, ANd Clifford Holcomb
}

Ro 21-3981 or MIDAZoLAM MALEATE is a benzodiazepine derivative closely related to diazepam. The structural formulae of Ro $21-3981$ and of three other commonly used benzodiazepine<smiles>CC(=O)N(C)C(=O)c1cc(Cl)ccc1N(C)C</smiles>

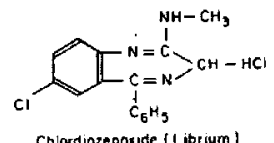

Diazepam (valium) Chlordiozepoxise (Librium )<smiles>O=C1NC(O)C(=O)Nc2ccccc21</smiles><smiles>Cc1ncc2n1-c1ccc(Cl)cc1C(c1ccccc1F)=NC2</smiles>

Ro 21 -39.91

Figure 1. Structural formulae of three commonly used benzodiazepine derivatives and the newly synthesized water soluble compound, Ro 21-3981.

drugs are shown in Figure 1. The major difference between the physical properties of Ro 21-3981 and diazepam is that Ro 21-3981 is water soluble, whereas diazepam is not. Because of its water solubility and other pharmacological properties common to the benzodiazapines, Ro 21-3981 is a promising drug for induction of anaesthesia. The purpose of this clinical investigation was to establish the effective sleep dose of Ro 21-3981 and to compare it with diazepam $0.3 \mathrm{mg} / \mathrm{kg}$.

\section{METHODS}

Thirty patients of ASA status I or II scheduled for elective surgical procedures were selected for study. The patients were informed of the possible risks associated with Ro 21-3981 and agreed to participate in the investigation. Ten additional

*Presented in part at the Annual Meeting of the American Society of Anaesthesiologisis at New Orleans, October 1977

J.G. Reves, M.D., Associate Professor, Guenter Corssen, M.D., Professor, and Clifford Holcomb, M.D., Assistant Professor. Department of Anaesthesiology, University of Alabama Medical Center, Birmingham, Alabama 35294.

Reprint requests to Dr. J.G. Reves.

Canad. Anaesth. Soc. J., vol. 25, no. 3, May 1978 patients agreed to receive diazepam $0.3 \mathrm{mg} / \mathrm{kg}$ and serve as a comparison group.

All patients came to the operating room unpremedicated. The standard lead II electrocardiogram was monitored continuously and blood pressure was measured every minute by the Riva-Rocci method. A metal Butterfly needle was placed into a vein on the dorsum of the hand* for injection of the anaesthetic drug. The patients were divided into four groups of ten patients each according to drug and dosage (Table I). Each

TABLE I

\begin{tabular}{lll}
\hline \hline Group I & Ro $21-3981$ & $0.10 \mathrm{mg} / \mathrm{kg}$ \\
Group II & Ro 21-3981 & $0.15 \mathrm{mg} / \mathrm{kg}$ \\
Group III & Ro $21-3981$ & $0.20 \mathrm{mg} / \mathrm{kg}$ \\
Group IV & Diazepam & $0.30 \mathrm{mg} / \mathrm{kg}$ \\
\hline
\end{tabular}

agent was given over 15 seconds and flushed in with an infusion of $50 \mathrm{ml}$ of five per cent dextrose in water. Patients breathed room air until after induction, when ventilation was assisted with 100 per cent oxygen. Induction of anaesthesia was defined as complete with loss of lid reflex and failure to respond to oral commands. The number of patients in each group and the time required for induction were recorded. The patients were observed for signs of pain with injection of the drugs and graded according to a scale of increasing severity $: 0=$ none $; 1=$ slight $; 2=$ moderate $; 3=$ severe.

Post-operative visits were made for three days to examine the injection site and to ascertain the patients' subjective evaluation of injection pain, if any. Signs of venous irritation were graded according to increasing severity on a scale of 0 to 3 and patients graded the severity of burning pain on injection of the anaesthetic on a scale of 1 to 3 . Those patients who had undergone anaesthesia in the past were asked to compare the induction with their previous anaesthetic experiences as either the same, better, or worse.

* Two patients in Group I did not have the metal needle, and received fluids and subsequent drugs through the same plastic cannula. 
TABLE II

Demographic Data of Patients

\begin{tabular}{|c|c|c|c|c|c|}
\hline & Number & Mean age & $\begin{array}{c}\text { Mean weight } \\
\text { (lbs) }\end{array}$ & $\begin{array}{l}\text { Mean duration } \\
\text { of anaesthesia } \\
\text { (min) }\end{array}$ & $\begin{array}{l}\text { With history } \\
\text { of previous } \\
\text { anaesthesia } \\
\text { (per cent) }\end{array}$ \\
\hline Group I & 10 & 34 & 174 & 120 & 90 \\
\hline Group II & 10 & 41 & 168 & 160 & 100 \\
\hline Group III & 10 & 52 & 151 & 122 & 80 \\
\hline Group IV & 10 & 48 & 172 & 102 & 80 \\
\hline
\end{tabular}

No significant difference in any category.

\section{Results}

The pertinent demographic data concerning the subjects are given in Table II and show no difference between the groups as far as sex, age,

TABLE III

Relation of Drug and Dosage to Effectiveness AND TIME OF INDUCTION

\begin{tabular}{lcc}
\hline \hline Group & Per cent induced & $\begin{array}{c}\text { Time of induction } \\
\overline{\mathrm{X}} \pm \text { S.E. }\end{array}$ \\
\hline $\begin{array}{c}\text { Ro } 21-3981 \\
(0.1 \mathrm{mg} / \mathrm{kg})\end{array}$ & 30 & $153 \pm 14.5$ \\
$\begin{array}{c}\text { Ro } 21-3981 \\
(0.15 \mathrm{mg} / \mathrm{kg})\end{array}$ & 50 & $107 \pm 19.1$ \\
Ro $21-3981$ \\
$(0.2 \mathrm{mg} / \mathrm{kg})$ \\
$\begin{array}{c}\text { Diazepam } \\
(0.3 \mathrm{mg} / \mathrm{kg})\end{array}$ & $100^{*}$ & $80 \pm 8.6$ \\
\hline $\begin{array}{l}\text { *P }<0.05 \text { Group III vs Groups I and II } \\
\dagger P<0.05 \text { Group IV vs Groups I and II. }\end{array}$
\end{tabular}

weight, duration of anaesthesia or history of previous anaesthesia are concerned. The effectiveness of Ro 21-3981 and diazeparn for induction is shown in Table III where the success of induction is directly related to dosage and time of induction inversely related to dosage. Mean time of induction was $80 \pm 8.6$ seconds for the ten patients in Group III, significantly $\mathrm{P}<0.05$ ) less than for Group $I$ in whom anaesthesia was induced with a mean time of $153 \pm 14.5$ seconds in three patients. There was no significant difference in induction times between Groups II, III, and IV.

The comparison of objective and subjective pain scores on induction is shown in Table IV along with post-operative severity of vein and tissue irritation and the patients' comparison of anaesthetic experiences. There was a doserelated increase in pain in patients receiving $R o$ 21-3981, but significantly $(P<0.05)$ less than that encountered with diazepam. There was no difference in vein irritation or phlebitis among the

TABLE IV

COMPARISON OF Ro 21-3981 and DIAZEPAM INDUCTION

\begin{tabular}{|c|c|c|c|c|c|c|c|}
\hline & \multirow{2}{*}{$\begin{array}{l}\text { Severity* } \\
\text { pain } \\
\text { objective } \\
\text { score }\end{array}$} & \multirow{2}{*}{$\begin{array}{l}\text { Severity* } \\
\text { pain } \\
\text { subjective } \\
\text { score }\end{array}$} & \multirow{2}{*}{$\begin{array}{l}\text { Severity* } \\
\text { of } \\
\text { irritation }\end{array}$} & \multirow{2}{*}{$\begin{array}{l}\text { Per cent } \\
\text { with } \\
\text { tissue } \\
\text { irritation }\end{array}$} & \multicolumn{3}{|c|}{$\begin{array}{l}\text { Comparison with previous } \\
\text { anaesthesia (per cent) }\end{array}$} \\
\hline & & & & & Same & Better & Worse \\
\hline $\begin{array}{l}\text { Group I } \\
\overline{\mathbf{X}} \pm \text { S.E. }\end{array}$ & $0.3 \pm 0.15$ & $0.5 \pm 0.27$ & $0.5 \pm 0.27$ & $20 \dagger$ & 55 & 45 & 0 \\
\hline$\frac{\text { Group II }}{\mathrm{X} \pm \text { S.E. }}$ & $0.5 \pm 0.22$ & $0.2 \pm 0.13$ & 0 & 0 & 30 & 70 & 0 \\
\hline $\begin{array}{l}\text { Group III } \\
\bar{X} \pm \text { S.E. }\end{array}$ & $0.5 \pm 0.17$ & $0.2 \pm 0.13$ & $0.1 \pm 0.1$ & 10 & 25 & 63 & 12 \\
\hline $\begin{array}{l}\text { Group IV } \\
\overline{\mathbf{X}} \pm \text { S.E. }\end{array}$ & $1.55 \pm 0.17$ & $0.8 \mp \pm 0.25$ & $0.1 \pm 0.1$ & 10 & 12 & 63 & 25 \\
\hline
\end{tabular}

*Scored: $0=$ little, 2 = moderate, $3=$ severe.

†These two patients received other intravenous medication and fluids through same intravenous infusion as used for induction.

$\pm P=<0.05$ diazepam vs all Ro 21-3981.

$\S \mathrm{P}=<0.05$ diazepam vs Ro $21-39810.15$ and $0.2 \mathrm{mg} / \mathrm{kg}$. 
groups. The two patients in Group [ who received multiple drugs and other fluids had some mild signs of tissue irritation consistent with extravenous infiltration. One patient each in Groups III and IV had evidence of mild venous and tissue irritation at the injection site. Patient acceptance was high (over 60 per cent) in Groups II, III, and IV; and unfavourable responses coincided with patients who had the greatest degree of discomfort on injection of the drugs.

\section{Discussion}

The benzodiazepines have common properties of sedation, hypnosis amnesia, anticonvulsant, and muscle relaxation.' As a class of drugs they are used as premedicants, ${ }^{2}$ anaesthesia induction agents ${ }^{3}$ and adjuvants in neuroleptanaesthesia. ${ }^{4}$ Of the benzodiazepine derivatives, diazepam has been used most frequently for induction of anaesthesia. It has minimal effects on the cardiovascular system," causes some respiratory depression, ${ }^{6}$ but is a suitable induction agent particularly in patients with ischaemic heart disease in whom there is evidence that coronary blood flow is maintained or increased ${ }^{7.8} \mathrm{~A}$ major disadvantage of diazepam is its insolubility in water, which necessitates the aqueous preparation in a vehicle of organic solvents which may irritate the vein and cause pain on injection.

The synthesis of Ro 21-3981 produced a benzodiazepine that is water soluble, yet is still closely related to diazepam in pharmacological properties. The present study compared the clinical efficacy of Ro 21-3981 and diazepam. Ro 21.3981 is approximately one and one-half times as potent as diazepam. The $\mathrm{ED}_{50}$ for Ro 21-3981 induction is $0.15 \mathrm{mg} / \mathrm{kg}$ and the $\mathrm{ED}_{100}$ induction dose is $0.2 \mathrm{mg} / \mathrm{kg}$ as compared to $0.3 \mathrm{mg} / \mathrm{kg}$ for diazepam. The onset of induction is more rapid with Ro 21-3981 than with diazepam ( $80 \mathrm{sec}$ vs 94 sec respectively). Ro 21-3981 was associated with significantly less objective and subjective pain on injection than was diazepam. Two patients had some evidence of venous irritation, but both had received multiple drugs and fluids through an intravenous catheter with possible subcutaneous infiltration.

Neither Ro 21-3981 nor diazepam were associated with severe complications. There was no hypotension, arrhythmia, or hiccups on induction. Apparent hypoventilation and apnoea requiring respiratory assistance encountered in both groups, and further studies are indicated to study in detail the respiratory effects of Ro 21 -
3981. The cardiovascular stability of diazepam was matched by Ro 21-3981, but this also must be studied in greater detail.

The half-life of Ro $21-3981$ is 1.7 hours ${ }^{9}$ and is therefore significantly shorter than that of diazepam. ${ }^{10}$ With this relatively shorter half-life the therapeutic effects of Ro 21-3981 should be shorter than diazepam. This aspect was not evaluated since the drugs were given for induction of different anaesthetics for operations of variable duration.

In conclusion, Ro $21-3981$ is a promising intravenous anaesthetic agent. It appears superior to the closely related benzodiazepine, diazepam. in that it is more potent, less irritating, and shorter acting. The drug merits further clinical trials.

\section{SUMmary}

Ro 21.3981 is a newly synthesized water soluble benzodiazepine derivative. Its pharmacological properties are similar to diazepam. This investigation was designed to establish the effective induction dosage of Ro 21-3981 and to compare it with diazepam for induction of anaesthesia. The $E D_{50}$ for Ro 21-3981 induction is 0.15 $\mathrm{mg} / \mathrm{kg}$ and $E D_{100}$ is $0.2 \mathrm{mg} / \mathrm{kg}$. Ro 21-3981 is one and one-half times as potent as diazepam 0.3 $\mathrm{mg} / \mathrm{kg}$ ) and more rapid in action. There is significantly less pain on injection with Ro 21-3981 as compared to diazepam. Cardiovascular stability and apnoea were observed with both drugs. Ro 2l-3981 is a promising anaesthetic induction drug that merits further human study.

\section{RÉSUMÉ}

Le RO-21-3981 est une nouvelle benzodiazépine de synthèse soluble dans l'eau. Ses propriétés pharmacologiques sont semblables à celles du diazepam.

Cette étude avait pour but de déterminer la dose efficace d'induction de cet agent et de comparer le RO-21-3981 au diazepam comme agent d'induction.

L'induction (perte du réflexe ciliaire et absence de réponse aux commandements) se produisait chez 50 pour cent des sujets à une dose de 0.15 $\mathrm{mg} /$ kilo et chez 100 pour cent des sujets avec 0.2 mg/kilo. Le RO-21-3981 est une fois et demie plus puissant que le diazepam (dose efficace : 0.3 $\mathrm{mg} / \mathrm{kilo}$ ) et plus rapide d'action que ce dernier.

Il est moins irritant que lui et cause moins de douleur en injection. On a observé avec les deux médicaments une grande stabilité cardiovas- 
culaire. Avec l'un comme avec l'autre, on peut rencontrer de l'hypoventilation et une apnée nécessitant une assistance respiratoire.

Le RO-2I-3981 nous semble un agent d'induction prometteur et mérite une étude plus poussée chez l'humain.

\section{RefERENCES}

I. Dundee, J.W. \& Haslett, W.H.K. The benzodiazepines: a review of their actions and uses relative to anaesthetic practice. Brit. J. Anesthesiology 42: 217-239 (1970).

2. Brandt, A.L. \& OAKes, F.D. Pre-anaesthesia medications: double-blind study of a new drug, diazepam. Anesth. and Analg. 44: 125-129 (1965).

3. Wyant, G.M. \& STUdNey, L.J. A study of diazepam (valium) for induction of anaesthesia. Canad. Anaesth. Soc. J. 17: 166-171 (1970).

4. Eisenberg, L., Taub, H.A., \& Burana, A. Memory under diazepam-morphine neuroleptanaesthesia in male surgical patients. Anesth. Analg. 53: 488-495 (1974).

5. Rao, S., Sherganiuk, R.W., Prasad, K., Lee,
S.J.K., \& SPROULE, N.J. Cardiopulmonary effects of diazepam. Clin. Pharmacol. Ther, 14: 182-189 (1972).

6. Catchlove, R.F.J. \& Kafer, E.R. The effects of diazepam on respiration in patients with obstructive pulmonary disease. Anesthesiology 34: 14-18 (1971).

7. Ikram, H., Rubin, A.P. \& Jewkes, R.F. Effect of diazepam on myocardial blood flow of patients with and without coronary artery disease, Brit. Heart J. 35: 626-630 (1973).

8. Cote, P., Gueret, P., \& Bourassa, M.G. Systemic and coronary hemodynamic effects of diazepam in patients with normal and diseased coronary arteries. Circulation 50: 1210-1216 (1974).

9. Brown, C.R., Sarnquist, F.H., \& Pedley, T.A. Ro 21-3981: clinical, electrocephalographic and pharmacokinetic study. (Abstract) Annual Meeting of Am. Soc. Anesth. 42l (1977).

10. Hillestad, L., Hansen, T., Melsame, H., \& DRIVENES, A. Diazepam metabolism in normal man: serum concentrations and clinical effects after intravenous, intramuscular, and oral administration. Clin. Pharmacol. Ther. 16: 479-489 (1974). 